
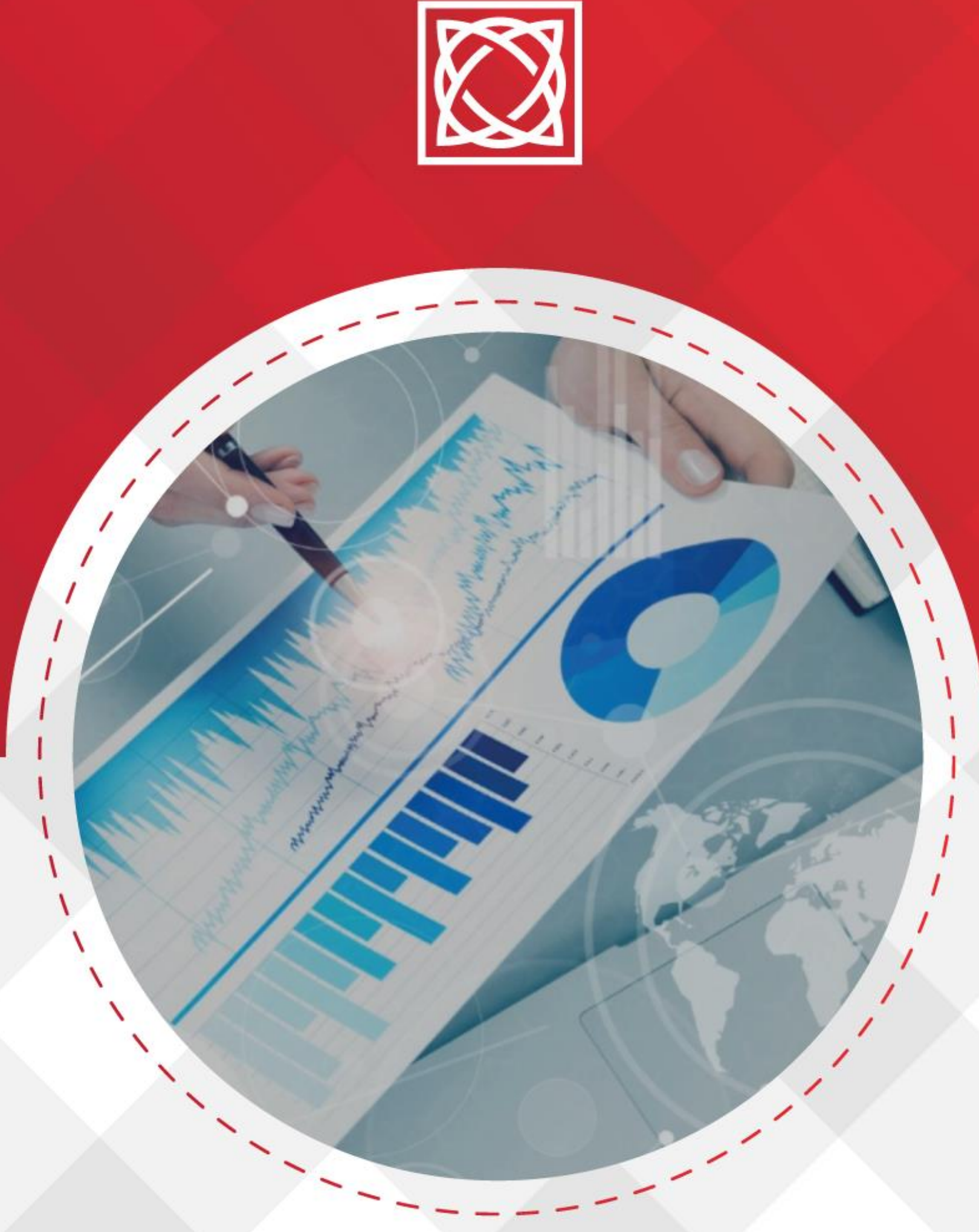

International Journal of

Economics, Management and Tourism 


\section{GOCE DELCEV UNIVERSITY OF STIP \\ FACULTY OF TOURISM AND BUSINESS LOGISTICS}

\section{INTERNATIONAL JOURNAL OF ECONOMICS, MANAGEMENT AND TOURISM \\ VOL. 1 NO. 1 \\ 2021}

ISSN 2671-3810 online version

ISSN 2671-3802 printed version 


\section{Publisher:}

Faculty of Tourism and Business Logistics

Goce Delchev University of Shtip

"Krste Misirkov" no.10-A P.O. Box 201 Shtip 2000, North Macedonia

Tel: +38932550 350

www.ftbl.ugd.edu.mk

www.ugd.edu.mk

\section{Editor in chief:}

Tatjana Boshkov, Ph.D.

\section{Editor:}

Natasha Miteva, Ph.D.

\section{Technical editor:}

Cvetanka Ristova Maglovska, Ph.D.

Dushko Joseski, Ph.D.

The International Journal of Economics, Management and Tourism (IJEMT) is peerreviewed and issued two times per year, in both print and online versions at the following website of the web portal of Goce Delcev University in Stip: https://js.ugd.edu.mk/index.php/ijemt/index. The official language for papers is English language.

IJEMT DOI: https://doi.org/10.46763/IJEMT

IJEMT Vol.1 No. 1 DOI: https://doi.org/10.46763/IJEMT2111 


\section{Editorial Board:}

Prof. Tatjana Boshkov, Ph.D., Goce Delcev University of Stip, Faculty of Tourism and Business logistics, Stip, North Macedonia

Assist. Prof. Natasa Miteva, Ph.D., Goce Delcev University of Stip, Faculty of Tourism and Business logistics, Stip, North Macedonia

Assist. Prof. Cvetanka Ristova Maglovska, Ph.D., Goce Delcev University of Stip, Faculty of Tourism and Business logistics, Stip, North Macedonia

Assist. Prof. Dusko Joseski, Ph.D., Goce Delcev University of Stip, Faculty of Tourism and Business logistics, Stip, North Macedonia

Prof. Ana Jurcic, Ph.D., Faculty of Business \& Economics, Department of Management \& Law, Modern College of Business \& Science

Prof. Jasmina Starc, Ph.D., Faculty of Business and Management Studies, University of Novo Mesto, Slovenia

Prof. Mirela-Elena Mazilu, Ph.D., Department of Geography, Director of Research Center in Innovative and Regional Tourism, University of Craiova, Romania

Prof. Kanita Imamovic-Cizmic, Ph.D., Faculty of Law, University of Sarajevo, Bosnia and Herzegovina

Prof. Slavi Petrov Dimitrov, Ph.D., Faculty of Economics, University St. Cyril and St. Methodius of Veliko Tarnovo, Bulgaria

Prof. Kemal Cebeci, Ph.D., Faculty of Economics, Department of Public Finance, Marmara University, Turkey

Prof. Sonja Cindori, Ph.D., Department of Financial Law and Financial Science, Faculty of Law University of Zagreb, Croatia

Prof. Boban Melovic, Ph.D., Faculty of Economics, University of Montenegro, Montenegro

Prof. Anton Vorina, School of Economics, Vocational College, Celje, Slovenia

Prof. Misko Djidrov, Ph.D., Goce Delcev University of Stip, Faculty of Mechanical Engineering, Stip, North Macedonia

Prof. Nikolas L. Hourvouliades, Ph.D., Americal College of Thessaloniki, Greece

Assist. Prof. Zarko Radjenovic, Ph.D., University of Nis, Innovation Center, Serbia

Prof. Madalina Teodora Andrei, Ph.D., Hyperion University, Faculty of Social, Humanities and Natural Sciences, Department of Geography, Romania

Biljana Conevska Gunjovska, Ph.D., Goce Delcev University of Stip, Faculty of Tourism and Business logistics, Stip, North Macedonia

Prof. Nazmiye Erdogan, Ph.D., Director of Vocational School of Social Science, Head of Tourism and Management, Department of Tourism Management, Ankara, Turkey Prof. Adam Pawlics, Ph.D., Chair of Tourism Management Department, Szczecin University, Poland

Prof. Rabi Kar, Ph.D., Associate Professor, Department of Commerce, University of Delhi, New Delhi, India

Prof. Tamara Klicek, Ph.D., National Taiwan University European Center and MOFA Foreign Schoolar, Taiwan

Prof. Iuliana Pop, Ph.D., University of Economics Studies, Bucharest, Romania Prof. Stefan-Emil Ionescu, Ph.D., Military Technical Academy, Bucharest, Romania Prof. Marta Borowska-Stefanska, Ph.D., University of Lodz Faculty of Geographical Sciences, Institute of the Built Environment and Spatial Policy, Poland 
Prof. Paolo Reis Mourao, Ph.D., Economics \& Management School, Department of Economics \& NIPE, University of Minho, Portugal

Prof. Mazhar Abbas, Ph.D., College of Business Administration, Department of Management \& MIC University of Ha'il Saudi Arabia

Prof. Drago Cvijanović, Ph.D., University of Kragujevac, Faculty of Hotel Management and Tourism in Vrnjacka Banja, Serbia 
TABLE OF CONTENTS

FOREWORD

Dejan Metodijeski; Oliver Filiposki

ANALYSIS OF WINE TOURISM OFFER IN NORTH MACEDONIA 8

Nikola Dimitrov

IDENTIFICATION DEFINITION, DETERMINATION AND PROMOTION OF LARGE

MOUNTAIN TOURIST REGIONS IN THE WORLD ............................................ 18

Dushko Josheski; Tatjana Boshkov

SIMULATING THE DIAMOND-PISSARIDES-MORTENSEN MODEL: SEARCH

MODEL THAT GIVES REALISTIC ACCOUNT OF UNEMPLOYMENT ..

Dushko Kocev

OUTSOURCING STRATEGY: OUTSOURCING THE FINANCE AND ACCOUNTING

FUNCTION BY SMEs

Marija Magdinceva Sopova \& Aneta Stojanovska Stefanova

THE IMPACT OF COVID PANDEMIC AND THE POLICY ACTION FOR

RECOVERY OF THE SMALL AND MEDIUM ENTERPRISES

Cane Koteski; Blerta Zimeri

WINTER TOURISM IN NORTH MACEDONIA AND ITS IMPACT IN THE

ECONOMIC GROWTH

Flori Asani; Perparim Qahili

SALT AND SEASONINGS AS A FOOD PRODUCTS. 75

Baton Zimeri; Erda Shabani

TREND OF GROSE POLISED PREMIUMS ACCORDING TO INSURANCE CLASSES. COMPARATION 2020 WITH 2019 


\title{
THE IMPACT OF COVID PANDEMIC AND THE POLICY ACTION FOR RECOVERY OF THE SMALL AND MEDIUM ENTERPRISES
}

\author{
Marija Magdinceva-Sopova, ${ }^{1}$ Aneta Stojanovska-Stefanova ${ }^{2}$ \\ 1 University Goce Delcev-Stip, e-mail:marija.magdinceva@ugd.edu.mk \\ 2University Goce Delcev-Stip, e-mail: aneta.stojanovska@ugd.edu.mk \\ ${ }^{*}$ Corresponding author: marija.magdinceva@ugd.edu.mk
}

\begin{abstract}
The current pandemic circumstances caused by the impact of the COVID-19 virus is an obstacle for the management of small and medium enterprises (SMEs). Due to the crisis, the management of SMEs is forced to introduce changes and policies in order to quickly adapt to the changes in the environment and overcome the situation swiftly.

It is an indisputable fact that the SMEs are drivers of the inclusive economic growth and operators for creating productive and sustainable occupations. Therefore, the subject of this paper focuses on recognizing the negative effects on the work of the SMEs caused by the impact of the COVID-19 virus and the pandemic, as well as the policies and measures taken by management and the state in order to overcome the situation, which has been going on for two years.

The changes in the life and the work that consist of the introduction of restrictive measures, changes in the social life of people have caused reduced workload or the closure of many SMEs for a certain period of time. This paper presents an overview of the impact of the COVID19 virus on the work of the SMEs, as well as the policies and measures implemented by the SMEs and the state in order to overcome the situation.

The main focus of the paper is on the operational adjustment policies of the enterprises implemented by the managers in the new working conditions.
\end{abstract}

Keywords: strategy, negative effects, state measures, pandemic

JEL Classification: L20, L26, L1

\section{INTRODUCTION}

The global health crisis caused by the impact of the COVID-19 virus is in a way forcing managers to make significant changes in the operations in order to quickly adapt the operations to the changes in the environment. Globalization increases the inequality in relations between the countries and especially the economic and the social inequality (Hurrell A.and Woods N., 1999, 15-35). Successful projects are a basic goal for managers and the changed working conditions caused by the impact of COVID-19 virus are both a challenge and an opportunity. In order to successfully cope with the impact of the health and economic crisis, different types of restrictive measures have been introduced in different time periods in the past two years. Restrictive measures and policies have led to changes that have manifested themselves in reduced physical socialization, inability to leave home at certain hours, limited movement, reduced working hours and, in the worst case, the closure of enterprises. As a result of the impact of the COVID-19 virus crisis on a global scale, the greatest negative consequences have been observed in the SMEs operating in the tourism and hospitality sector as well as in the other industries such as construction, crafts and transport. New economic conditions have imposed the need for companies to change the traditional organization and structure of work and the development of information and 
communication technology has enabled the emergence of new organizational structures that differ from those based on the static concept (Lukic A, Novovic M., 2021, 79).

Changes in the global environment have led a number of SMEs to focus on the introduction of digitalization policies and measures in the operation, whereby many of the core activities have shifted to digital way of performing and applying various IT devices in the operation. This process leads to the creation of new businesses and the transformation of enterprises by renewing the basic ideas (Guth, W. D., and Ginsberg, A. 1990, 5-15). The digitalization and application of IT devices and programs are the mechanisms through which companies have successfully faced the challenges of the pandemic. Adapting to the new situation is associated with the effort of the management of enterprises to become enterprises that are constantly learning and transferring new skills, techniques (Magdinceva-Shopova M., StojanovskaStefanova A. and Postolov, K., 2020, pp.1-17). In contrast, companies whose core business depends on the physical presence of visitors or consumers, such as hospitality and tourism companies, such as hotels, restaurants and cafes, and other similar businesses, have suffered heavy losses. These types of companies were forced to reduce the number of employees for a certain period of time. In order to reduce the negative impact of the health crisis, the management of the SMEs has adopted appropriate policies and measures. The state has also implemented an appropriate set of measures in the form of financial assistance such as: financial support for the payment of net salaries to employees, providing financial assistance to small enterprises to pay bills, financial assistance to small and medium enterprises to employ new employees, reduction at the interest rate on loans and reprogramming of the overdue debts.

\section{MATERIAL AND METHODS}

SMEs faced serious financial problems due to the pandemic and unfavorable business climate. The introduction of restrictions and restrictions have helped to reduce consumption which has directly affected the reduction of corporate revenues. Small enterprises, due to their small size and resources, find it difficult to adapt to the current situation and changes in the work environment. The protracted duration of the crisis has forced businesses to adapt to change. The introduction of restrictive policies and measures has contributed to the change in the organization of work in enterprises. The distancing measures helped to reorganize the execution of work activities. Many companies have introduced telecommunications as one of the safest ways to respond to a crisis. Many companies focused on the most important work activities that can be accomplished through remote work or work from home. In order to see the activities undertaken by the management of enterprises to adapt to the new situation and the need to implement appropriate policies for the "recovery" of the enterprises, a practical survey was conducted. The practical research was conducted using the method of a questionnaire which consisted of 10 questions from a content point of view. The research was conducted electronically in the period from 01.09.2021 until 31.11.2021. The survey questionnaire was submitted to 130 SMEs. Out of the 130 questionnaires submitted, feedback was received from 75 managers of small and medium enterprises who showed interest and answered the questions from the survey questionnaire. During the preparation of this paper, the method of analysis and the method of synthesis were used, as well as the specific, quantitative and interrelated scientific methods - modern methods and classical methods of analysis.

\section{RESULTS AND DISCUSSION}

As a result of the answers received from the survey and based on the number of total observations of each question, it is concluded that the survey questionnaire which was 
submitted to the managers of SMEs and answered by 75 respondents. Most of the surveyed companies (36\%) belong to the tourism and catering industry. An overview of the structure of the activity of the companies involved in the research is given in Figure 1.

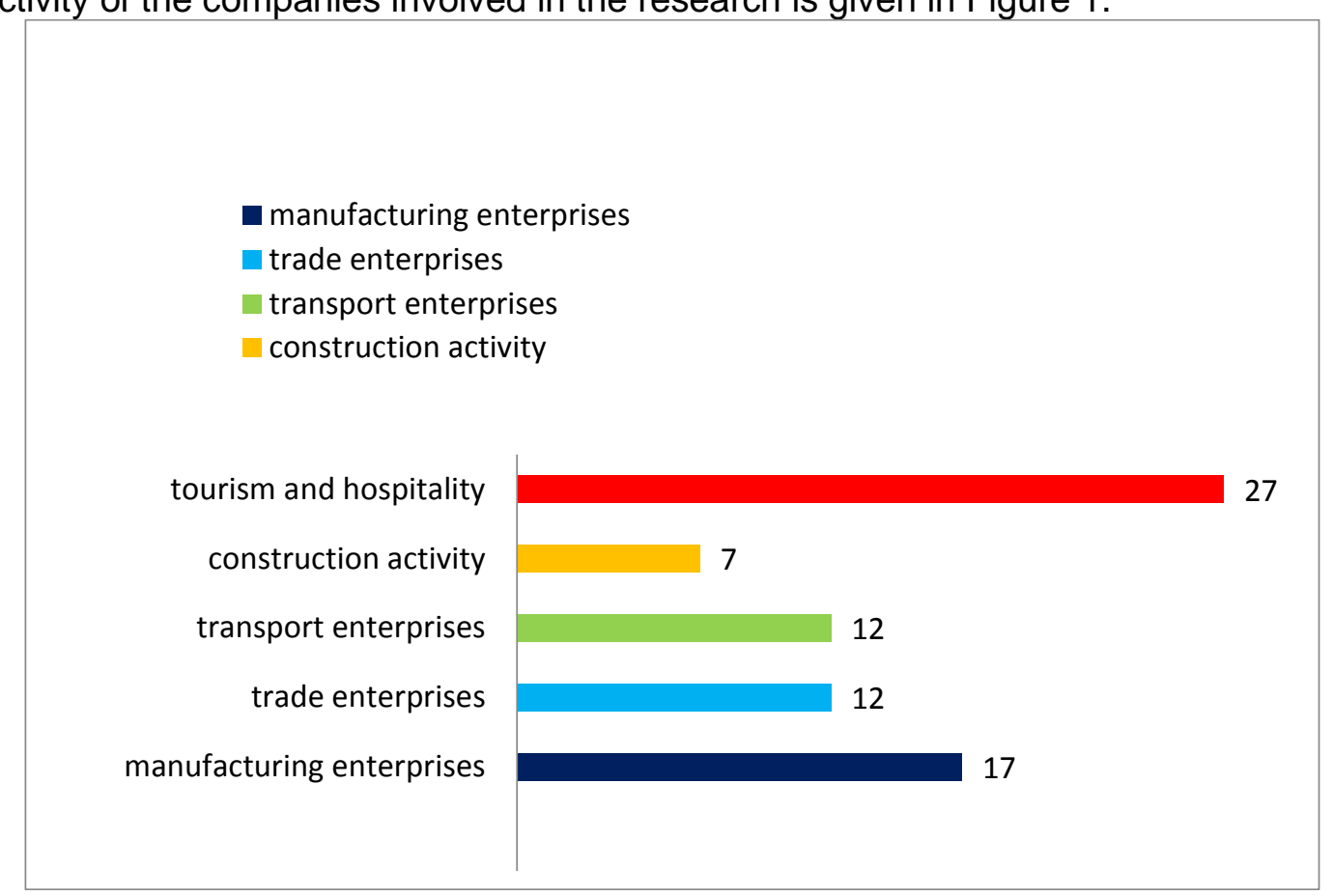

Figure 1. Structure of the enterprises involved in the research by occupation

According to the answers to each question, it is concluded that on the first question - Did you make changes in the work as a result of the introduced restrictive measures?, all managers answered positively to the question, ie 75 respondents said they had introduced organizational changes in the work. The results obtained are graphically shown in Figure 2.

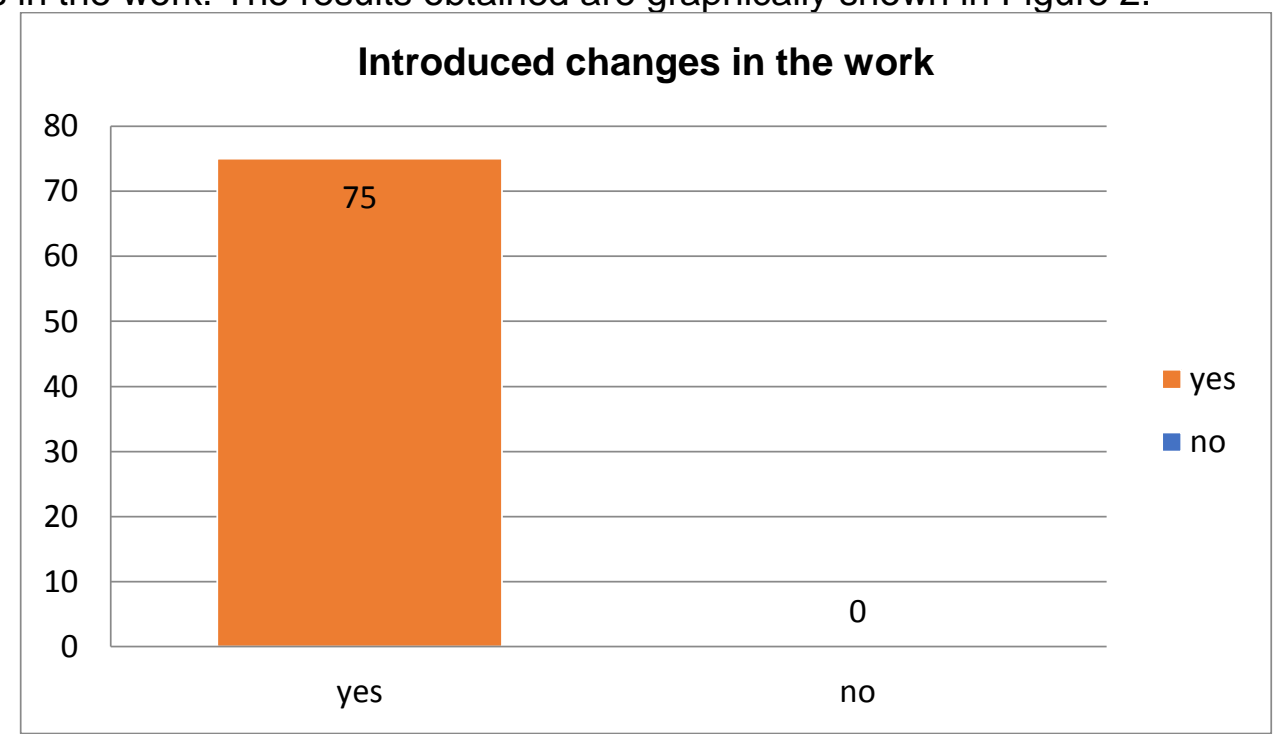

Figure 2: Graphic presentation of the results of the question - Did you make any changes in the work as a result of the restrictive measures introduced? Source: Own research Regarding the second question from the conducted survey- Have you introduced measures to reduce working hours?, the following answers were received: 56 managers answered that working hours have been reduced and 19 managers answered that the working hours of the 
company have not been reduced as a result of restrictions imposed due to the pandemic. The results obtained are shown in Figure 3.

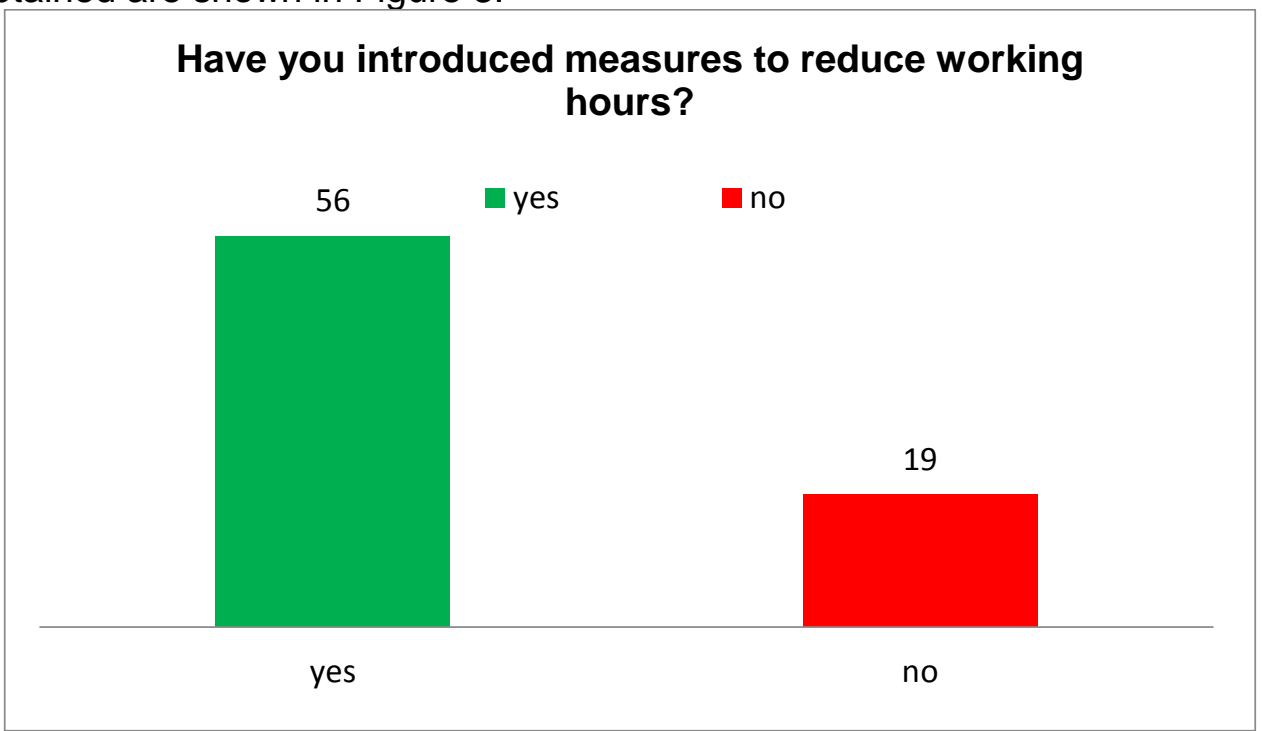

Figure 3: Graph of the results of the question - Have you introduced any measures to reduce working hours? Source: Own research

Did you introduce shift work? - is the third question in the survey. The majority of the asked managers or 34 companies stated that they did not introduce shift work and 41 managers stated that they introduced shift work. The results obtained are graphically shown in Figure 4.

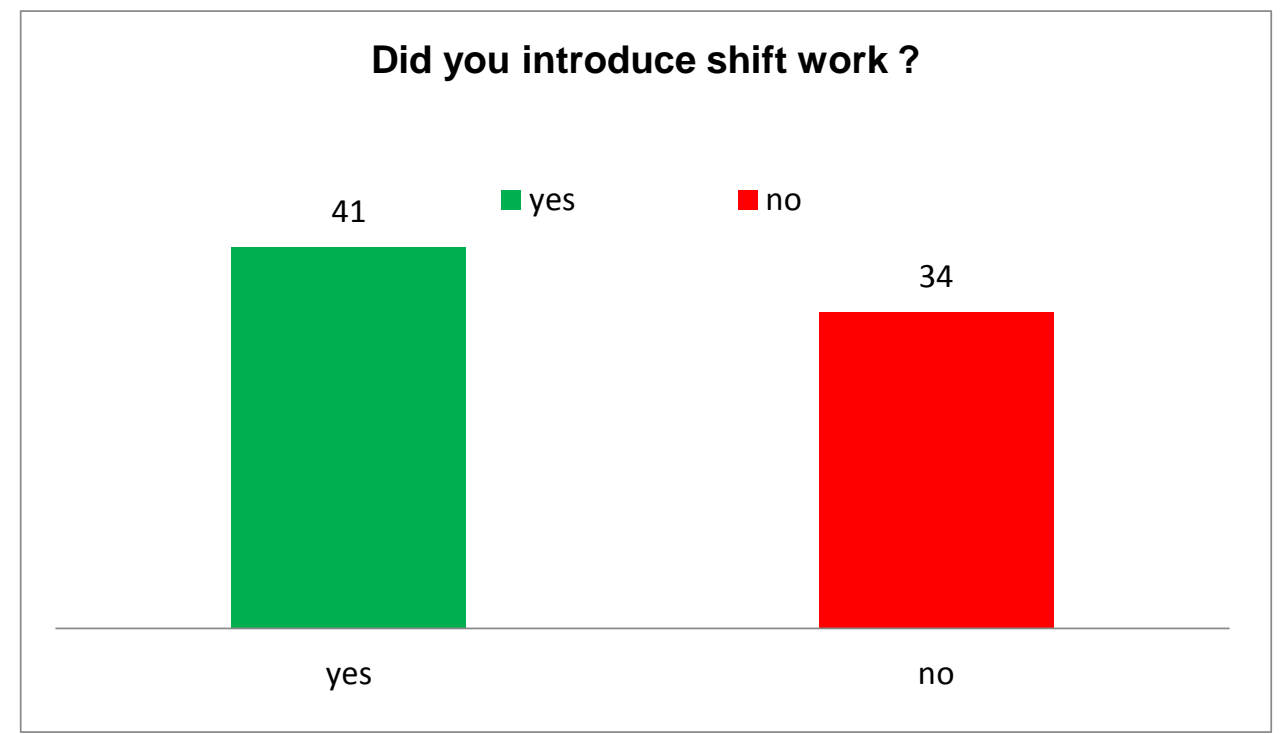

Figure 4: Graphical presentation of the results of the question - Did you introduce shift work? Source: Own research

On the fourth question regarding the statement on whether the home resource management methods were introduced, most of the respondents or 46 managers stated that they have not introduced policies and practices for work from home due to the nature of the work and 29 managers stated that the execution of work activities was diverted from home. The obtained results are graphically shown in Figure 5. 


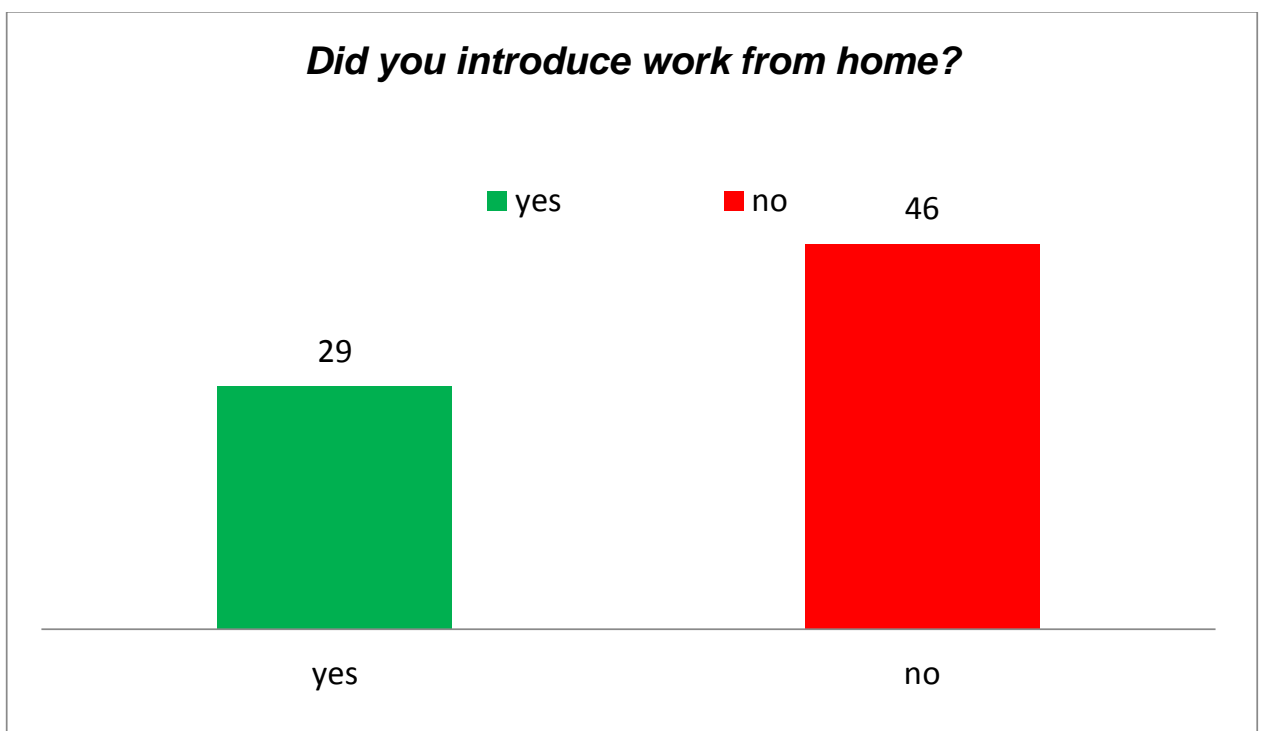

Figure 5: Graph of the results of the question - Did you introduce work from home? Source: Own research

The following question in the survey was - Have you introduced policies to change the approach to consumers?, most of the managers surveyed or 58 managers have introduced policies to adapt to the needs of consumers and 17 managers answered that they have not introduced changes. The results of the answers to this question are graphically shown in Figure 6.

\section{Have you introduced policies to change the approach to consumers?}

$$
\text { ayes } \quad \text { no }
$$

58

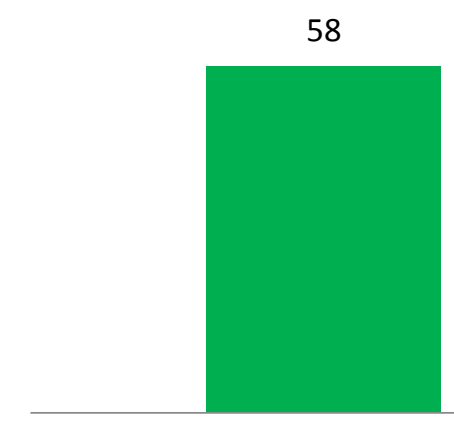

yes
17

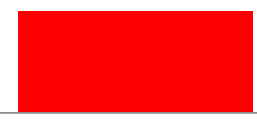

no

Figure 6: Graph of the results of the question - Have you introduced policies to change the approach to consumers? Source: Own research

The next question in the survey was related to the consumer access policies or more precisely as follows - What consumer access policies and changes have you introduced? (A) online sales, b) home delivery or $\mathrm{c}$ ) online sales and home delivery, which only applies to managers who have responded to the previous question positively, the following answers were received: 45 managers practice to apply in the work of companies both forms of work - online sales and home delivery, 11 companies work on the principle of home delivery and only two companies work by applying the policy of online sales . Figure 7 shows the answers of this question. 


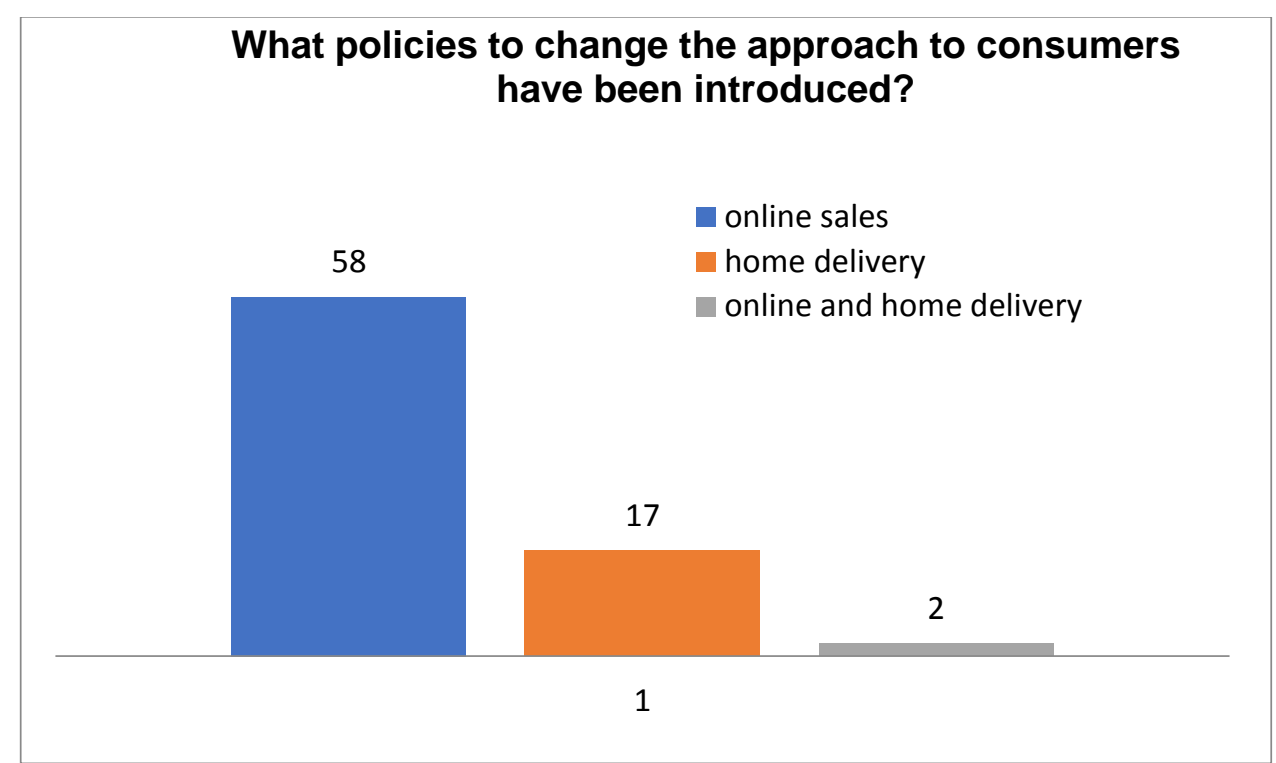

Figure 7: Graph of the results of the question - What consumer access policies and changes did you introduce? Source: Own research

The next question from the questionare - Have any changes been introduced in the offer assortment?, 43 of the managers involved in the survey stated that their companies have changed the range and 32 companies have not made any changes to the offer range. The received answers are graphically shown in Figure 8.

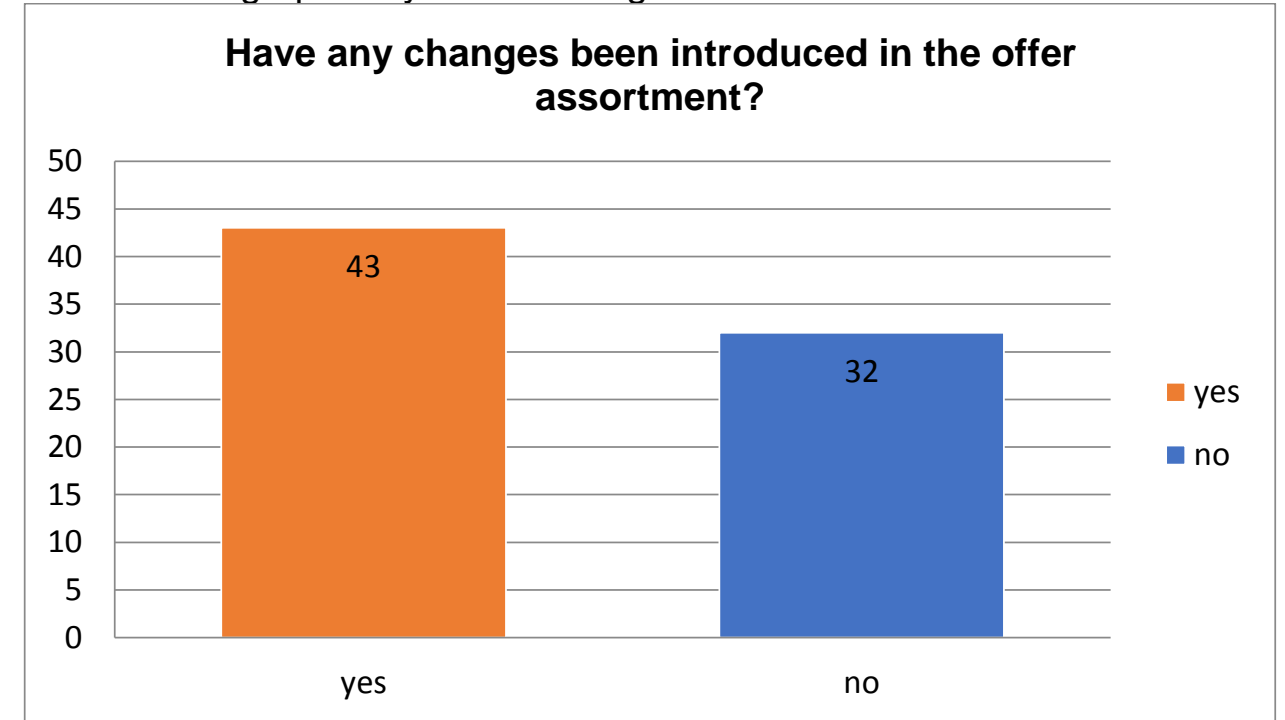

Figure 8: Graphic presentation of the results of the question - Have any changes been introduced in the offer assortment? Source: Own research

In our survey managers and companies were asked with the next question - As a result of restrictive measures, whether the company stopped working for a certain period of time?, 35 managers said that their companies did not stop working and 40 companies stopped working. The answers obtained are shown in Figure 9. 


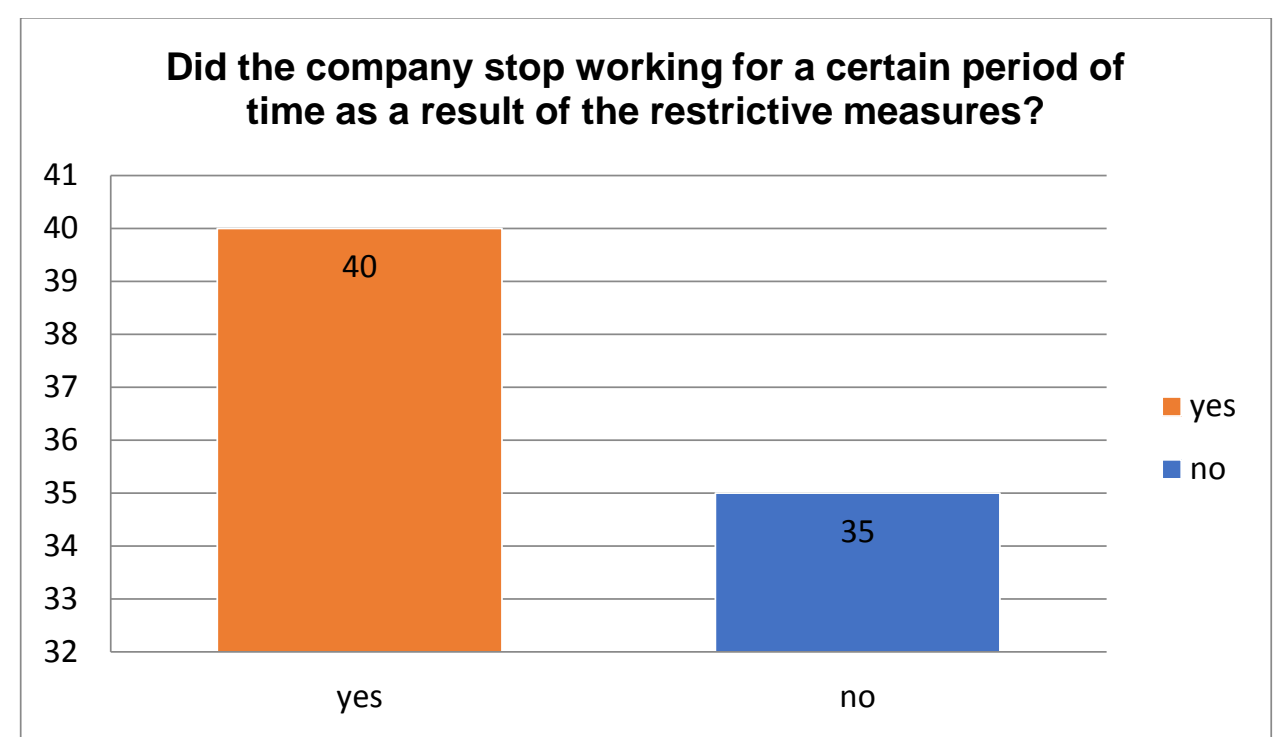

Figure 9: Graphic presentation of the results of the question - Did the company stop working for a certain period of time as a result of the restrictive measures? Source: Own research Regarding the ninth question which refers only to the companies that have a work stoppage or a total of 40 companies - What is the time period of the work stoppage?, a) up to 30 days b) up to 90 days c) up to 180 days, 4 companies have a work stoppage up to 30 days, 26 companies or most of the respondents have a work stoppage of up to 90 days and 10 companies have a work stoppage of up to 180 days. The answers to this question are shown in Figure 10.

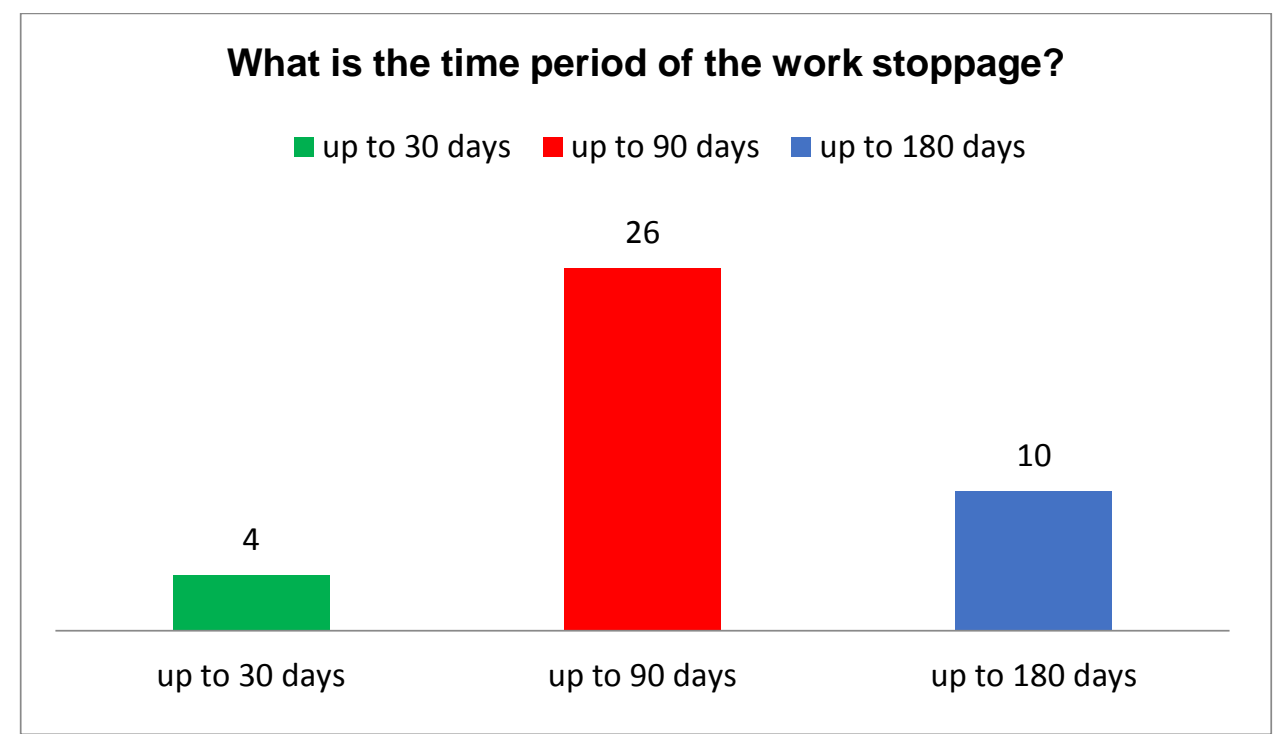

Figure 9: Graphic presentation of the results of the question - What is the time period of the work stoppage? Source: Own research

Last but not the least - the tenth question regarding the companies that had interruptions - Did you reduce the number of employees during the interruption of work? 2 companies did not reduce the number of employees. Figure 10 graphically shows the received answers. 


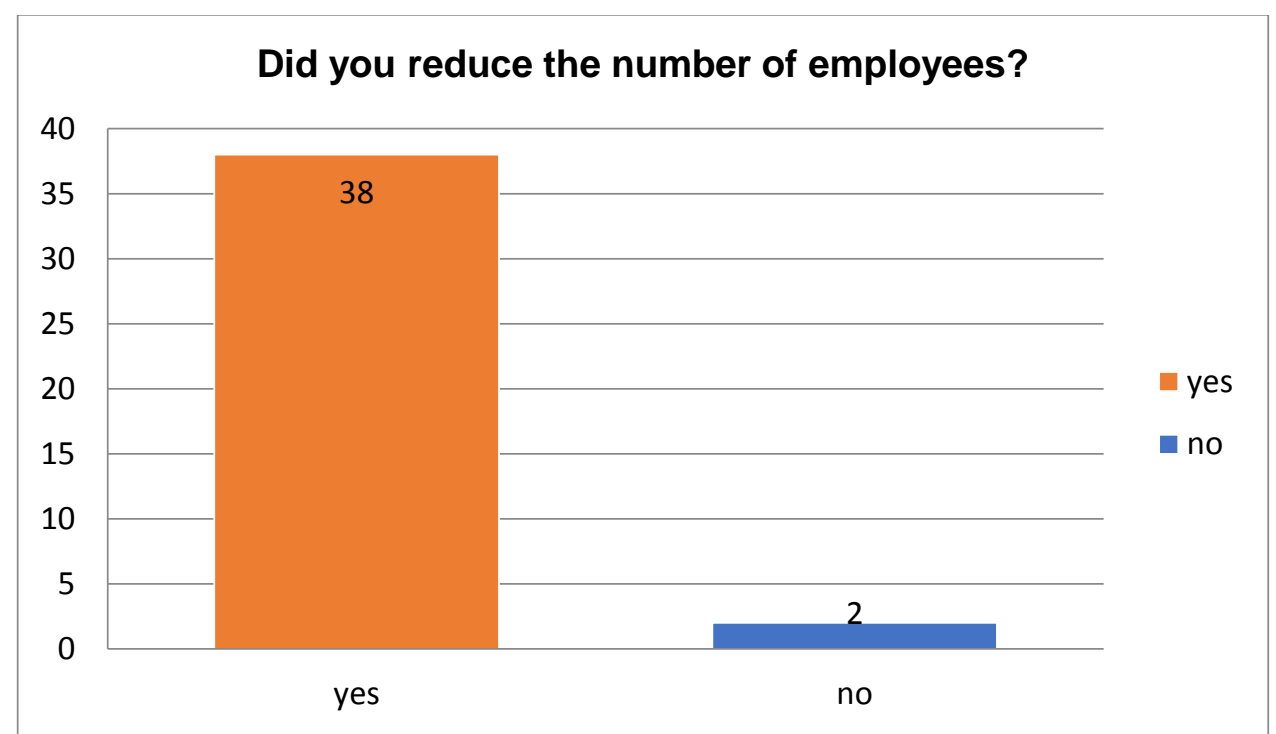

Figure 10: Graph of the results of the question - Did you reduce the number of employees? Source: Own research

\section{CONCLUDING REMARKS}

The health crisis caused by the impact of the COVID-19 virus followed by the economic crisis are the most important issues for the functioning of economic processes worldwide. This situation has prompted managers to think about a number of issues related to the implementation of appropriate policies and measures for the operation of companies in crisis situations. The impact of the health crisis has contributed to the introduction of restrictive measures and restrictions as well as special rules of operation that have forced the managers to introduce changes in the current operations of companies. The crisis is a phenomenon that negatively affects the business efficiency, business performance, ie the company and success in achieving the set goals (Radovanovic T., 2004, 19-21). According to the results obtained from the conducted research, it is concluded that this situation and the introduction of restrictive measures and policies caused changes in all companies in order to adjust the situation, such as introduction of shift work, reduction of working hours, work from home (on online platforms), changes in access to consumers and changes in supply. Adapting to the new situation is related to the effort of the management to timely identify the causes of crises. This crisis means that there are unforeseen crises including the current pandemic caused by the COVID-19 virus which has a major impact on society (Ratten Vanesa, 2020, 503-516). Prolonged non-operation and restrictive policies have contributed to many negative effects on the operation of enterprises, such as interruptions in the ongoing operation for a certain period of time (from 30 days to 180 days depending on the condition of the enterprise). The economic challenges of the health crisis have not been overcome and many enterprises can not be solvent and financially stable due to which the management of the enterprises should focus on the introduction of new policies and methods of work. Cooperation is also needed to deal with the COVID-19 virus crisis, especially with regard to knowledge sharing. (Kirk and Rifkin, $2020,124-131)$ As a result of the global health crisis, corporate management needs to make quick decisions and to adapt to the changes in the environment. Uncertainty about future operations is present because the crisis caused by the Covid-19 virus still exists (Magdinceva Sopova M., Stojanovska-Stefanova A. and Postolov K., 2021, 171-175). 


\section{REFERENCES}

1. Guth, W. D., and Ginsberg, A. (1990). Guest Editors' Introduction: Corporate Entrepreneurship. Strategic Management Journal, 11(5), 5-15

2. Hurrell A.and Woods N. (1999), Inquality, Globalization and World Politics, Oxford, Oxford University Press,15-35

3. Magdinceva-Sopova Marija and Stojanovska-Stefanova Aneta and Postolov, Kiril (2020) Impact of Covid-19 on human resources in small and medium enterprises: the case of Macedonia. International Journal Knowledge, pp.1-17

4. Magdinceva Sopova, Marija and Stojanovska-Stefanova, Aneta and Postolov, Kiril (2021) Types of crises in the work of entrepreneurs: The impact of the global health crisis. Knowledge - International Journal Vol.46.1., 46 (1). pp. 171-175

5. Лукиќ А, Нововиќ М., (2021), Accounting and audit in theory and practice, Бања Лука Колеџ, 2021, стр.79

6. Kirk, C. P., and L. S. Rifkin. (2020) "I'll Trade You Diamonds for Toilet Paper: Consumer Reacting, Coping and Adapting Behaviors in the COVID-19 Pandemic." Journal of Business Research 117: 124-131

7. Ratten Vanesa,(2020), Coronavirus (covid-19) and entrepreneurship: changing life and work landscape, Journal of Small Business \& Entrepreneurship, VOL. 32, No.. 5, 503-516

8. Радовановиќ Т. (2004),Успешен Претприемач, Нови Сад, стр 19-21 